\title{
Single tooth morse taper implant placement and restoration immediately after extraction
}

\author{
Reabilitação bucal com implante cone morse e prótese \\ unitária imediatamente após exodontia
}

\author{
Fernando Santos CAUDURO'1 iD 0000-0003-1622-030X \\ Daniela Nascimento SILVA² (D) 0000-0003-0145-2247 \\ Rogério Belle de OLIVEIRA ${ }^{1}$ iD 0000-0002-4661-3377 \\ Márjorie das Posses BRIDI ${ }^{3}$ iD 0000-0001-7227-0462 \\ Daniel Esteves CAUDURO4 ${ }^{4}$ 0000-0003-4926-4982 \\ Salete Maria PRETTO ${ }^{1}$ iD 0000-0003-4937-8381
}

\section{ABSTRACT}

Objective: to analyze aesthetic and functional outcomes of the rehabilitation of single tooth morse taper implant restoration with single crown prosthesis immediately after tooth extraction. Methods: Retrospective longitudinal clinical study of 57 patients submitted to an oral rehabilitation protocol with morse taper (Ankylos ${ }^{\circledR}$ Classic) dental implants, without performing incision, grafts nor suture, followed by the placement of a provisional prosthesis immediately after tooth removal in the anterior maxillary region. The pre-and post-operative clinical data (alveolar bone contour at vestibular aspect, soft tissue contour at cervical aspect and papillae level) and postoperative radiographic findings (bone height / implant ratio) were submitted to descriptive statistics (mean and standard deviation) and Fisher's Exact Test. Results: the implant success rate was $98.25 \%$. The alveolar bone vestibular aspect was maintained in $69.6 \%$ of the cases. There was no soft tissue retraction on the cervical aspect and the papillae height was preserved in $89.3 \%$ of the cases. The bone level remained above the implant neck in $92.8 \%$ of the cases. There was no significant association between implant diameter and soft tissue retraction $(p=0.910)$ or retraction of the interproximal papilla $(p=0.148)$ or resorption of the alveolar bone crest $(p=0.610)$. Conclusion: This protocol is characterized by the application of minimally traumatic techniques, reducing rehabilitation time and offering positive aesthetic and functional results.

Indexing terms: Dental implants. Mouth rehabilitation. Osseointegration.

\section{RESUMO}

Objetivo: Analisar os resultados estéticos e funcionais da reabilitação bucal com implante cone morse e prótese provisória unitária imediatamente após exodontia. Métodos: Estudo clínico longitudinal retrospectivo de 57 pacientes submetidos a um protocolo

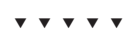

1 Pontifícia Universidade Católica do Rio Grande do Sul, Faculdade de Odontologia. Av. Ipiranga, 6681, Prédio 06, Partenon, 90619-900, Porto Alegre, RS, Brasil. Correspondência para / Correspondence to: FS CAUDURO E-mail: <fercau@terra.com.br>.

2 Universidade Federal do Espírito Santo, Curso de Odontologia, Departamento de Clínica Odontológica. Vitória, ES, Brasil.

3 Universidade Federal do Espírito Santo. Vitória, ES, Brasil.

${ }^{4}$ Associação Brasileira de Odontologia - Seção Rio Grande do Sul, Curso de Atualização de Cirurgia Oral Menor. Porto Alegre, RS, Brasil.

$\boldsymbol{\nabla} \mathbf{v} \mathbf{v}$

How to cite this article

Cauduro FS, Silva DN, Oliveira RB, Bridi MP, Cauduro DE, Pretto SM. Single tooth morse taper implant placement and restoration immediately after extraction. RGO, Rev Gaúch Odontol. 2019;67:e20190043. http://dx.doi.org/10.1590/1981-86372019000433609 
de reabilitação bucal com implantes osseointegráveis cone morse (Ankylos® Classic.), sem incisão, sem enxertos e sem sutura, seguida de instalação de prótese provisória unitária imediatamente após exodontia em região estética maxilar. Os dados clínicos pré e pós-operatórios (contorno alveolar vestibular, contorno gengival cervical e papilas) e radiográficos pós-operatórios (relação nível ósseo/ implante) foram submetidos a estatística descritiva (média e desvio-padrão) e ao Teste Exato de Fisher. Resultados: A taxa de permanência dos implantes foi de 98,25\%. O contorno alveolar vestibular foi mantido em 69,6\% dos casos. Não houve retração do contorno cervical gengival e as papilas foram preservadas em $89,3 \%$ dos casos. O osso se manteve acima do espelho do implante em $92,8 \%$ dos casos. Não houve associação significativa entre diâmetro do implante e retração gengival $(p=0,910)$ ou retração da papila gengival $(p=0,148)$ ou ainda reabsorção da crista óssea alveolar $(p=0,610)$. Conclusão: Este protocolo caracteriza-se por técnicas minimamente traumáticas, reduz o tempo da reabilitação e oferece bons resultados estéticos e funcionais.

Termos de indexação: Implantes dentários. Reabilitação bucal. Osseointegração.

\section{INTRODUCTION}

For many years, the success of oral rehabilitation using dental implants has been associated with strict protocols, which pursue long periods of bone healing without the interference of occlusal forces to achieve osseointegration. The technological advances made regarding the improvement of dental implants' designs and surfaces have been helping increase primary and secondary stability, leading to a shorter period of osseointegration, besides favoring the preservation of alveolar bone height with aesthetic purposes. This predictability in implant therapy encouraged several reassessments of the protocol established by Branemark [1]. In the original treatment protocols, dental extraction was required beforehand, and implant placement was only performed after alveolar bone neoformation [2]. However, the need to reduce treatment duration led to the investigations, since the 1990s, on immediate implant placement and prosthetic rehabilitation, both at the same time as surgical tooth extraction. In addition to reduced treatment time, this approach also reduces the number of surgical interventions and can improve aesthetic results. As there is no flap elevation and tissue manipulation is reduced, the risk of bone resorption or soft tissue retraction is also reduced [3].

The negative outcomes of a tooth loss are well known and documented, especially in the anterior region, such as bone atrophy with functional and aesthetic impairment, increase in duration and difficulty of the prosthetic rehabilitation. In some patients, the time waiting for osseointegration to occur may induce psychological, social and / or functional problems. Among the causes for tooth loss are root fracture, periodontal impairment, failure of endodontic treatment and untreated cavities [4].

This paper proposes an oral rehabilitation protocol involving the immediate placement of a morse taper implant and single crown prosthesis rehabilitation in a series of fresh extraction sockets, evaluating the clinical behavior of this therapy with a five-year follow-up.

\section{METHODS}

This research was approved by the local Ethics Committee under number 1329/08. This is a retrospective longitudinal clinical study from data gathered from dental records of 57 patients submitted to oral rehabilitation with osseointegrated morse taper Ankylos ${ }^{\circledR}$ Classic dental implants (Friadent GmbH, Mannheim, Germany) placement and the subsequent installation of a single tooth temporary prosthesis immediately after tooth extraction. One implant was installed in each patient. Patients were treated at a private dental clinic. Patients who performed tooth extraction in the upper premolar, canines and incisors areas and had a history of good general health were included in the sample. The exclusion criterion was presence of local acute infection.

After imaging analysis, and according to the bone availability of each patient, there were selected and installed $133.5 \mathrm{~mm}$ diameter implants, $314.5 \mathrm{~mm}$ diameter implants and $135.5 \mathrm{~mm}$ diameter implants, with length varying from $8 \mathrm{~mm}$ to $17 \mathrm{~mm}$.

\section{Surgical and prosthetic protocol}

- Preoperative medication: systemic antibiotic therapy with Amoxicillin 2g, 01 hour before the procedure, and 500mg every 8 hours for 07 days post-operatively;

- Local anesthesia with $2 \%$ lidocaine with 1: 100,000 adrenaline;

- Minimally traumatic tooth extraction: careful syndesmotomy without manipulating the interproximal papillae, for teeth with coronary remnants it should be performed delicate dislocation and dental avulsion with 
forceps, while the roots are dislocated and avulsed with periotomes. No incision or mucoperiosteal detachment is to be performed. If necessary, it is recommended odontosection, avoiding osteotomy;

- Alveolar curettage should be performed in case there is presence of chronic inflammatory processes, observed clinically and / or radiographically;

- Abundant irrigation of the alveolus with saline solution;

- Milling sequence and placement of morse taper implant (Ankylos ${ }^{\circledR}$ Classic, Friadent $\mathrm{GmbH}$, Mannheim, Germany) according to the manufacturer, favoring primary stability. Expanders, condensers and Summers osteotomes may be used. It is advised to use the longest possible implant, to enable anchorage in the regions beyond the alveolar apex. Regarding the implant diameter, once stability is achieved with the $3.5 \mathrm{~mm}$ bone expander, the $3.5 \mathrm{~mm}$ implant is indicated. On the other hand, if there is mobility or slack with this expander, drilling should be continued with a $4 \mathrm{~mm}$ drill. If stability is achieved, a $4.5 \mathrm{~mm}$ implant should be placed. If not, the procedure is to continue expanding the implant bed to receive larger diameter implants, or one could choose not to install any implant in this section and wait for alveolar healing to apply the conventional protocol;

- There is no need for suturing. No bone grafts or any alloplastic material or membranes are used between the implant and the alveolar vestibular wall. This gap is filled only by the blood clot (table 1);

- The single tooth immediate provisional prosthesis is made with Duralay ${ }^{\circledR}$ self-curing acrylic resin and prefabricated teeth veneers, sealing the cavity to stabilize the clot and support the gingival tissues. The prosthesis should be free of occlusal and lateral contacts. According to the proposed protocol, patients should remain with the provisional prosthesis for a period of at least three months;

- For postoperative analgesia it is recommended: paracetamol 750mg, 01 tablet every 6h, for 02 days or in case of pain;

- Patients were instructed to perform careful tooth brushing, topical use of chlorhexidine at $0.12 \%$ at the implant site, 3x / day, for one week. Continuously apply ice packs on the operated area for 10 minutes then rest 30 minutes. Repeat this procedure for the first 6 hours. Eat only cold liquid-pasty food in the first 24 hours, gradually increasing food consistency. Do not chew directly on implant site within the first 60 days.

\section{Radiographic analysis}

Radiographic examinations available in the patients' charts such as periapical and panoramic radiographs were assessed to evaluate the indication for exodontia and immediate implant installation. In the immediate postoperative period (up to 07 days) a panoramic radiograph was used to determine the relation of the implant with the adjacent anatomical structures, and periapical radiography to evaluate the bone-implant tissue interface and to observe the peri-implant radiolucent areas peculiar to alveolar anatomy, but also due to the dimensions of the extraction socket being a larger than those of the inserted implant. In the postoperative period (minimum of 90 days) before the definitive unitary prosthesis was made, periapical radiography was assessed to evaluate the bone-implant tissue interface, observing peri-implant bone neoformation and to detect signs that may point to defects in osseointegration, as well as assess the marginal bone level (above, below or at the level of the implant neck) and its alterations.

Table 1. Oral rehabilitation protocol with morse taper implant and immediate provisionalization after tooth extraction. Porto Alegre (RS), 2019.

\begin{tabular}{|c|c|}
\hline Protocol & Surgical approach \\
\hline Inspection and curettage & No periosteum detachment \\
\hline Morse taper implant placement & No graft \\
\hline Single tooth provisional closing the gap & No membrane \\
\hline
\end{tabular}




\section{Evaluation of clinical data}

Clinical and photographic data were collected from the patients' charts at different time periods. The clinical characteristics of the pre and postoperative peridental tissues were: normal gingival contour or cervical retraction (identified by root or prosthetic metallic component exposure); normal or retracted interproximal papillae (when there was interdental cervical exposure); presence of inflammatory process (present or absent vestibular fistula); and contour of the vestibular alveolar bone wall (bone contour over the root portion of the tooth to be extracted and of the implanted area, classified as preserved, flat or concave). Clinical results after application of the protocol were assessed after at least 90 days and longitudinally up to 60 months.

Data were submitted to descriptive statistics (mean and standard deviation). Fisher Exact Test was used to analyze the correlation between implant diameter and gingival retraction variables, characteristics of the gingival papilla and resorption of the alveolar bone crest, showing statistically significant results for $p<0.05$. In this study the ethical principles mentioned in the Declaration of Helsinki (2000) were fulfilled.

\section{RESULTS}

After immediate implant and temporary rehabilitation, the 57 patients were followed for up to 5 years (60 months), with an average of 34 months of follow-up. The implant permanence rate was $98.25 \%$ (56 implants), and there was a loss of one implant in the upper central incisor area (1.75\%) 35 days after its insertion in a patient with anterior open bite.

The vestibular alveolar contour was preserved in $69.6 \%$ of the cases (39 patients). There was no retraction of the gingival cervical contour and the papillae were preserved in $89.3 \%$ of the individuals (50 patients). The bone remained above the neck of the implant, in the mesial and distal, in $92.8 \%$ of the cases (52 patients). In 5,4\% of the cases ( 3 patients) the bone was below the neck and in only 1 patient ( $1.8 \%$ of the cases) the bone was at the level of the neck of the implant.

The periapical radiographic examinations allowed to evaluate the osseointegration, due to the absence of radiolucent image around the implant, as well as the bone height in the mesial and distal alveolar ridge region, adjacent to the implant neck, and to establish if there was bone maintenance, loss or neoformation in this implant region (figure 1).

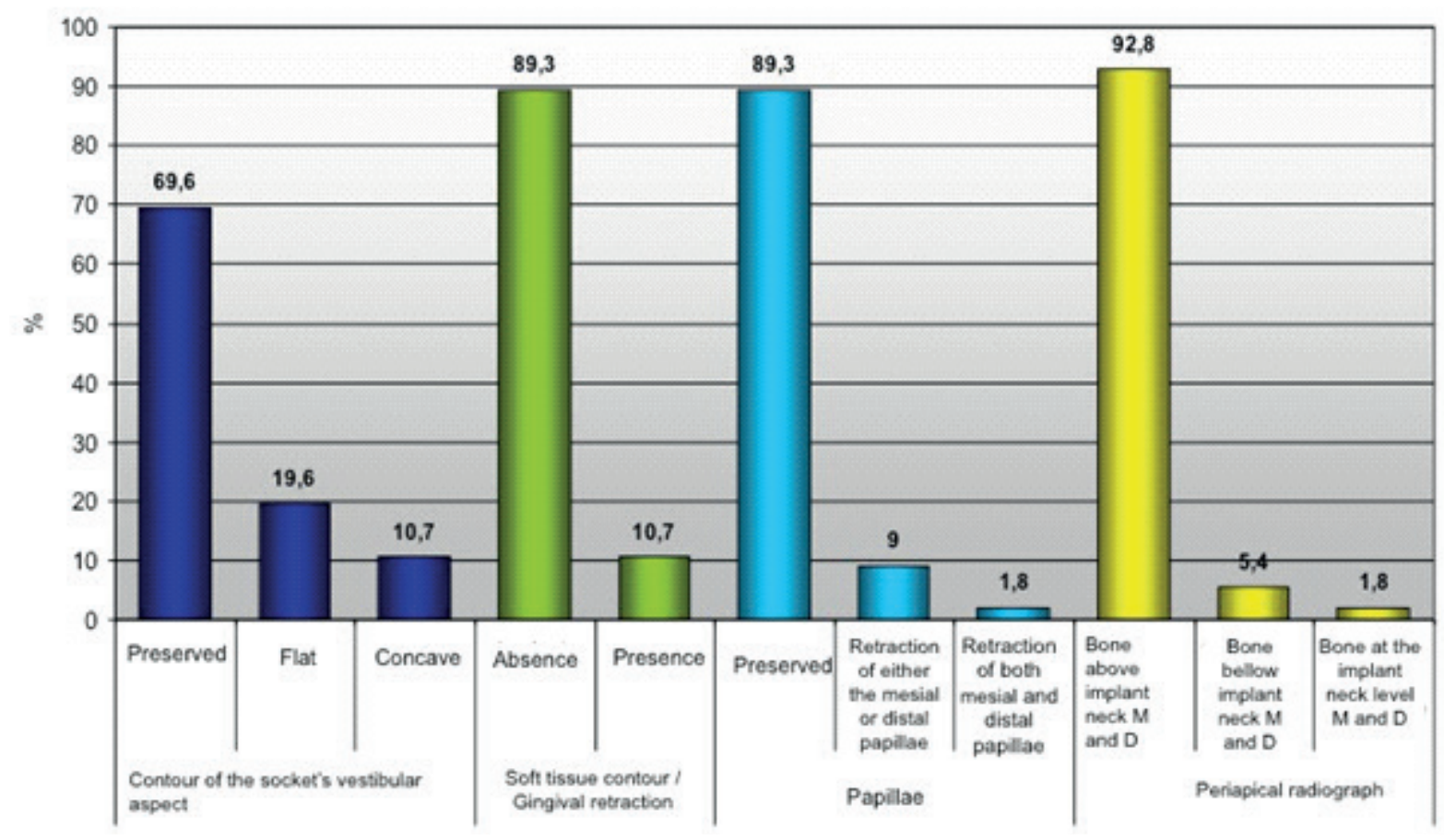

Figure 1. Frequency distribution of the cases studied according to the variables related to the clinical and radiographic postoperative evaluation. Porto Alegre (RS), 2019. 
Through the results of Fisher's Exact Test, there was noted no significant association between implant diameter and gingival retraction $(p=0.910)$, gingival papilla retraction $(p=0.148)$ and bone resorption and / or neoformation in the bone crest alveolar region, observed through periapical radiography $(p=0.610)$ (table 2$)$. There was 1 case of vestibular gingival retraction with exposure of the threads of an implant measuring $5.5 \mathrm{~mm}$ in diameter by $11 \mathrm{~mm}$ in length installed in the right upper central incisor area.

\section{DISCUSSION}

This study evaluated bone and gingival remodeling after the installation of immediate implants with immediate provisional restoration, without the use of grafts and sutures. The results of this study were similar to those reported by Nentwig [5] who obtained a 98.7\% permanence rate in an 11-year follow-up of morse taper implants, also using the Ankylos ${ }^{\circledR}$ system. There are no pre-established criteria for the shape of the implants, reason why there is so much research done in order to test different materials, surfaces and threads design and also aiming to improve osseointegration through modifications in the receptor bone tissue. The current research used morse taper implants with progressive threads for oral rehabilitation. According to Steigenga et al. [6], modifications in the design of the body and surface of the implants suggest increased success in low quality bones due to a greater anchorage and bone-implant

Table 2. Correlation between implant diameter and gingival retraction, aspect of the gingival papilla and resorption of alveolar bone crest in the postoperative follow-up. Porto Alegre (RS), 2019.

\begin{tabular}{|c|c|c|c|c|c|c|}
\hline & \multirow{2}{*}{ Parameters } & \multicolumn{3}{|c|}{ Implant diameter } & \multirow{2}{*}{ Total } & \multirow{2}{*}{$p$-value* } \\
\hline & & $3.5 \mathrm{~mm}$ & $4.5 \mathrm{~mm}$ & $5.5 \mathrm{~mm}$ & & \\
\hline \multirow{4}{*}{ Gingival retraction } & Moderated & & $1(100.0 \%)$ & & $1(100.0 \%)$ & \multirow{4}{*}{$p=0.910$} \\
\hline & Little & $1(20.0 \%)$ & $3(60.0 \%)$ & $1(20.0 \%)$ & $5(100.0 \%)$ & \\
\hline & Absent & $12(24.0 \%)$ & $26(52.0 \%)$ & $12(24.0 \%)$ & $50(100.0 \%)$ & \\
\hline & Total & $13(23.2 \%)$ & $30(53.6 \%)$ & $13(23.2 \%)$ & $56(100.0 \%)$ & \\
\hline \multirow{3}{*}{ Interproximal papilla } & $\begin{array}{l}\text { Retraction of both mesial and distal } \\
\text { papillae }\end{array}$ & & $1(100.0 \%)$ & & $1(100.0 \%)$ & \multirow{3}{*}{$p=0.148$} \\
\hline & Maintained & $13(26.0 \%)$ & $27(54.0 \%)$ & $10(20.0 \%)$ & $50(100.0 \%)$ & \\
\hline & Total & $13(23.2 \%)$ & $30(53.6 \%)$ & $13(23.2 \%)$ & $56(100.0 \%)$ & \\
\hline \multirow{2}{*}{$\begin{array}{l}\text { Alveolar bone crest } \\
\text { (radiographic evaluation) }\end{array}$} & Bone bellow implant neck $\mathrm{M}$ and $\mathrm{D}$ & $1(33.3 \%)$ & $2(66.7 \%)$ & & $3(100.0 \%)$ & \multirow{2}{*}{$p=0.610$} \\
\hline & Bone above implant neck $\mathrm{M}$ and $\mathrm{D}$ & $12(23.1 \%)$ & $28(53.8 \%)$ & $12(23.1 \%)$ & $52(100.0 \%)$ & \\
\hline
\end{tabular}

$\mathrm{M}=$ Mesial; $\mathrm{D}=$ Distal; $\mathrm{mm}=$ millimeters. ${ }^{*}$ Fisher's exact test. Statistically significant for $\mathrm{p}<0.05$. 
contact surface. For Romanos et al. [7], the sandblasted surface of the Ankylos implant system may have a positive influence on bone integration under load due to its high porosity. For De Castro et al. [8], the morse taper system presents less bone remodeling, without micromovements between the intermediate prosthetic piece and implant, and bone tissue present until the level of the connection with the prosthetic abutment. It is installed bellow bone level aiming to increase soft tissue availability to enable final gingival conditioning and achieve adequate esthetics by means of temporary crowns.

In the evaluated protocol, the implant is positioned more palatally, no incisions, flaps nor periosteal detachments are used, maintaining the buccal bone vasculature in order to preserve the buccal bone and the interproximal papillae. Tooth extraction should be atraumatic, preserving the bone margins of the alveolus during extraction [9]. The atraumatic procedure decreases bone resorption, since it minimizes the interruption of the vascular supply to the wall of the buccal aspect of the socket, which, especially in the anterior maxilla, is usually very thin [10]. Implants placed more buccally in the extraction sockets are significantly associated with gingival recession [2].

In the proposed protocol, the presence of inflammation and / or chronic infection in the alveolus was not a contraindication for the tooth extraction followed by implant installation. However, complete curettage and rising of the alveolus should be considered as an important step of the surgical procedure in the presence of these alterations. Otherwise, alveolar curettage should not be performed, maintaining the remnants of the fibers of the periodontal ligament in the alveolus, in order to favor repair. Lee et al. [11] evaluated the survival rate of immediate implants in areas of periapical lesions and found that the results were the same for immediate implants placed at sites with periapical lesions, immediate implants placed in healthy sites, and late implant placement at sites with periapical lesion. This highlights the similar clinical feasibility of the three procedures.

Chaushu et al. [12] included among the factors that influence the stability of the immediate implant, the potential area of the bone-implant surface (length, width, thread type versus cylinders and microtexture), bone quality and initial bone-implant contact. The authors advocated the use of wider and longer implants. Kan et al. [13], on the other hand, in a 5-year retrospective study, from clinical and radiographic data of 35 immediate implants installed, demonstrated that the amount of recession can be significantly reduced using a narrower diameter implant in the esthetic zone. There was a significant increase of recession among sites with a thin gingival biotype versus a thick biotype. The most significant finding was the correlation between $3.5 \mathrm{~mm}$ diameter implants and minimal recession. In the current study, the protocol recommends using the smallest diameter possible. However, favorable results were found among all the implant diameters used and the variables of gingival aesthetics and height of the alveolar bone crest, with no statistical difference among them. It is important to note that the contour and gingival aesthetics were preserved in all smaller diameter implants $(3.5 \mathrm{~mm})$. Only one case presented vestibular gingival recession with exposure of the threads in a wide diameter implant (5.5mm).

Regarding gingival and bone remodeling, Ross et al. [14] studied the time period in which gingival recession occurs around implant rehabilitation. The highest recession rate of was observed until the first month, and this resorption continued at a smaller rate within the first 3 months after the final restoration. De Rouck et al. [15] and Palattella et al. [16] reported that most of the recession occurred within the first 6 months after definitive restoration. Sites adjacent to natural teeth have been shown to be less likely to have bone loss than sites located adjacent to edentulous areas. Cardaropoli et al. [17] reported that bone remodeling in the immediate implant procedures occurs within 4 months after implant placement.

Alveoli of newly extracted teeth and surgically created sockets exhibit different behaviors in regenerative procedures. It is possible to hypothesize that healing in these alveoli is better due to the high growth potential. In this study, after implant placement, the space between the implant and the vestibular aspect was filled exclusively by blood clot, without the interposition of any substances such as autogenous grafts or biomaterials because it is believed that the clot is stable enough to promote bone neoformation, similar to conventional socket healing. Hämmerle et al. [18] reported that in perimplantar gaps of $2 \mathrm{~mm}$ or less, spontaneous bone healing and osseointegration occurred when titanium implants with rough surface were used. Zani [19] states that this marginal gap between the bone tissue and the surface of the implant that was placed immediately after extraction can heal without the use of barrier or filling material, even those gaps larger than $4 \mathrm{~mm}$. 
In all cases, immediate implant placement and restoration was recommended, favoring the stabilization of the clot and providing support for the soft tissues, without any need for sutures. It is recommended to install the definitive intermediate prosthetic piece with a temporary crown in acrylic resin, temporary abutment and cemented with provisional cement, without lateral nor centric contacts $[20,21]$. Patients were instructed to avoid masticatory loading in the implanted region for a period of three months. In the studies by Chen and Buser [2], lower gingival recession of the buccal mucosa in implants with immediate temporary restoration were observed in comparison with the group where the late restoration was performed.

Cone-beam CT studies have been set in motion in order to evaluate hard and soft tissue remodeling in immediate implant restorations in maxillary aesthetic region, providing more information due to the possibility of three-dimensional evaluation [22].

\section{CONCLUSION}

The proposed protocol is distinguished by minimally traumatic and effective techniques that reduce the overall time of rehabilitation. It is a predictable and safe treatment assured by positive aesthetic and functional results, becoming a viable alternative of oral rehabilitation with morse taper implant and single tooth provisional in aesthetic areas of the maxilla immediately after dental tooth extraction.

\section{Collaborators}

FS CAUDURO, study design, clinical trial execution, textual elaboration, review and approval of the final manuscript text. DN SILVA, textual elaboration, revision and approval of the final text of the manuscript. RB OLIVEIRA, study design, review and approval of the final manuscript text. MP BRIDI, bibliographical update and textual elaboration. DE CAUDURO, execution of the clinical experiment. SM PRETTO, study design, review and approval of the final manuscript text.

\section{REFERENCES}

1. Nkenke E, Lehner B, Fenner M, Roman FS, Thams U, Neukam FW, et al. Immediate versus delayed loading of dental implants in the maxillae of minipigs: follow-up of implant stability and implant failures. Int J Oral Maxillofac Implants. 2005; 20(1): 39-47.

2. Chen ST, Buser D. Esthetic outcomes following immediate and early implant placement in the anterior maxilla: a systematic review. Int J Oral Maxillofac Implants. 2014;29:186-215. http://dx.doi.org/10.11607/jomi.2014suppl.g3.3.

3. Takeshita K, Vandeweghe S, Vervack V, Bruyn H. Imediate implant placement and loading of single implants in the esthetic zone: clinical o utcom e and esthetic evaluation in a japanese population. Int J Periodontics Restorative Dent. 2015;35:715-23. http://dx.doi.org/10.11607/prd.2494

4. Cardaropoli D, Tamagnone L, Roffredo A, Gavelio L. Soft tissue contour changes at immediate postextraction singletooth implants with immediate restoration: a 12-month prospective cohort study. Int J Periodontics Restorative Dent. 2015;35:191-8. http://dx.doi.org/10.11607/prd.2326

5. Nentwig GH. The ANKYLOS implant system: concept and clinical application. J Oral Implantol. 2003;30(3):171-7.

6. Steigenga JT, al-Shammari KF, Nociti FH, Misch CE, Wang $\mathrm{HL}$. Dental implant design and its relationship to long-term implant success. Implant Dent. 2003;12(4): 306-17.

7. Romanos GE, Toh CG, Siar CH, Swaminathan D. Histologic and histomorphometric evaluation of peri-implant bone subjected to immediate loading: An experimental study with Macaca Fascicularis, Int J Oral Maxillofac Implants. 2002; 17(1): 44-51.

8. De Castro DSM, Araujo MAR, Benfatti CAM, De Araujo CRR, Piattelli A, Perrotti $V$, et al. Comparative histological and histomorphometrical evaluation of marginal bone resorption around external hexagon and morse cone implants: an experimental study in dogs. Implant Dent. 2014; 23(3): 2706. http://dx.doi.org/10.1097/ID.0000000000000089

9. Lindhe J. Tratado de periodontia clínica e implantologia oral. $5^{\mathrm{a}}$ ed. Rio de Janeiro: Guanabara Koogan; 2010.

10. Cristalli MP, Marini R, La Monaca G, Sepe C, Tonoli F, Annibali $\mathrm{S}$. Immediate loading of post-extractive single-tooth implants: a 1-year prospective study. Clin. Oral Impl. Res. 2015;26: 1070-9. http://dx.doi.org/10.1111/clr.12403

11. Lee CT, Chuang SK, Stoupel J. Survival analysis and other clinical outcomes of immediate implant placement in sites with periapical lesions: systematic review. Int J Oral Maxillofac Implants. 2015;30(2):268-78. http://dx.doi.org/10.11607/ jomi.3619

12. Chaushu G, Chaushu S, Tzohar A, Dayan D. Immediate loading of single-tooth implants: immediate versus non immediate implantation. A clinical report. Int J Oral Maxillofac Implants. 2001;16(2): 267-72.

13. Kan JY, Rungcharassaeng K, Lozada JL, Zimmerman G. Facial gingival tissue stability following immediate placement and provisionalization of maxillary anterior single implants: a 2- to 8-year follow-up. Int J Oral Maxillofac Implants. 2011;26:179-187.

14. Ross SB, Pette GA, Parker WB, Hardigan P. Gingival margin changes in maxillary anterior sites after single immediate implant placement and provisionalization: a 5-year retrospective study of 47 patients. Int J Oral Maxillofac Implants. 2014;29(1):127-34. http://dx.doi.org/10.11607/jomi.3124 
15. De Rouck T, Collys K, Cosyn J. Immediate single-tooth implants in the anterior maxilla: a 1-year case cohort study on hard and soft tissue response. J Clin Periodontol. 2008; 35: 649-65. http://dx.doi.org/10.1111/j.1600-051X.2008.01235.x

16. Palattella P, Torsellow F, Cordano L. Two-year prospective clinical comparison of immediate replacement vs immediately restoration of single tooth in the esthetic zone. Clin Oral Implants Res. 2008; 19(1): 1148-53. http://dx.doi.org/10. 1111/j.1600-0501.2008.01578.x

17. Cardaropoli D, Gaveglio L, Gherlone E, Cardaropoli G. Soft tissue contour changes at immediate implants: a randomized controlled clinical study. Int J Periodontics Restorative Dent. 2014; 34(5): 631-7. http://dx.doi.org/10.11607/prd.1845

18. Hämmerle $\mathrm{CH}$, Chen ST. Wilson TG Jr. Consensus statements and recommended clinical procedures regarding the placement of implants in extraction sockets. Int J Oral Maxillofac Implants. 2004; 19: 26-8.

19. Zani SR. Immediate implant placement into extraction socket a clinical case report. Odontol. Clin Cient. 2011; 10(3): 281-4.
20. Silva RJ, Silva FPQ, Carvalho JP, Ferreira FC. Immediate implant placement in esthetic zone. Dental Press Implantol. 2013; 7(2): 67-72.

21. Levin BP, Wilk BL. Immediate provisionalization of immediate implants in the esthetic zone: a prospective case series evaluating implant survival, esthetics, and bone maintenance. Compend Contin Educ Dent. 2013; 34(5): 352-61.

22. Roe $P$, Kan JYK, Rungcharassaeng K, Caruso JM, Zimmerman G, Mesquida J. Horizontal and vertical dimensional changes of peri-implant facial bone following immediate placement and provisionalization of maxillary anterior single implants: a 1-year cone beam computed tomography study. Int J Oral Maxillofac Implants. 2012; 27(2): 393-400.

Received on: 18/9/2018

Final version resubmitted on: 15/11/2018

Approved on: 8/2/2019 